\title{
Radioactivity in the Atmosphere
}

\author{
By H. W. Gäggeler \\ Institut für anorganische, analytische and physikalische Chemie, Labor für Radio- und Umweltchemie, \\ Universität Bern, 3012 Bern, Switzerland \\ and Labor für Radio- und Umweltchemie, Paul Scherrer Institut, 5232 Villigen PSI, Switzerland
}

(Received August 24, 1995)

\section{Radioactivity / Atmosphere / Radon / Thoron / Cosmogenic radionuclides}

\begin{abstract}
A short review is made on atmospheric radionuclides with emphasis on their activity concentrations in the troposphere, mostly for surface air over Europe. Discussed are those species which have activity concentrations above about $1 \mathrm{mBq} / \mathrm{m}^{3}$. For this atmospheric layer highest average activity concentrations $\left(\geq 1 \mathrm{~Bq} / \mathrm{m}^{3}\right)$ have i) ${ }^{222} \mathrm{Rn}$ ("radon") and its short-lived decay products, (ii) ${ }^{220} \mathrm{Rn}$ ("thoron"), however, only for the lowest meter above ground, and iii) ${ }^{85} \mathrm{Kr}$. In the range $1 \mathrm{mBq} / \mathrm{m}^{3}$ to $1 \mathrm{~Bq} / \mathrm{m}^{3}$ are $\mathrm{T}\left({ }^{3} \mathrm{H}\right),{ }^{14} \mathrm{C},{ }^{37} \mathrm{Ar}$ and ${ }^{7} \mathrm{Be}$ as well as the "thoron" decay product ${ }^{212} \mathrm{~Pb}$. Average activity concentrations slightly below $1 \mathrm{mBg} / \mathrm{m}^{3}$ has ${ }^{211} \mathrm{~Pb}$, the only long-lived decay product of "radon". The sources of these radionuclides are discussed. Not included in this review are radionuclides contained in the atmosphere at very low activity concentrations or from single emissions such as e.g. from the Tschernobyl accident in 1986.
\end{abstract}

\section{Introduction}

Environmental radioactive nuclides have three different sources; they are either primordial, cosmogenic or anthropogenic.

Primordial radionuclides are those which were produced during element evolution and which have (partly) survived since then due to their long half-lives. Our solar system has an age of about $4.5 \cdot 10^{9}$ years; this means that nuclides with half-lives longer than about $10^{8}$ years can still be found in our environment. With respect to the atmosphere, progenies of the primordial nuclides ${ }^{238} \mathrm{U}$ and ${ }^{232} \mathrm{Th}$ with half-lives of $4.5 \cdot 10^{9}$ and $1.4 \cdot 10^{10}$ years, respectively, are of special importance. These actinides are mainly contained in the lithosphere and decay via several nuclides to different isotopes of lead. In both decay chains one intermediate nuclide is an isotope of the noble gas radon, ${ }^{222} \mathrm{Rn}$ (called "radon") in case of ${ }^{238} \mathrm{U}$ and ${ }^{220} \mathrm{Rb}$ ("thoron") in case of ${ }^{232} \mathrm{Th}$ which have half-lives of 3.8 days and $56 \mathrm{~s}$, respectively. These gases can escape from the lithosphere into the atmospheres. Of less importance with respect to the atmosphere - is ${ }^{235} \mathrm{U}$ with a halflife of $7.0 \cdot 10^{8}$ years, caused by its low isotopic abundance of $0.7 \%$ in natural uranium and the fact that the corresponding radon isotope ${ }^{219} \mathrm{Rn}$ ("actinon") has a very short half-life of $4 \mathrm{~s}$.

The second reservoir of radionuclides is the upper atmosphere. The earth is permanently bombarded by cosmic ray particles. These particles are of solar or galactic origin and are predominantly protons. Mainly the high energy galactic protons (typical energies $100 \mathrm{MeV}-3 \mathrm{GeV}$ with a flux of about $3 \mathrm{~cm}^{-2} \mathrm{~s}^{-1}$ [1]) interact with the atmospheric species in nuclear reactions and form a variety of radionuclides. Also secondary particles such as neutrons and myons have high enough energies to produce several nuclides. The beam flux of galactic cosmic ray particles onto the earth surface is not constant in time; it is modulated by the solar activity which has a well known 11 year cycle. In time periods with high solar activity (i.e. high sun spot number) the flux of galactic particles bombarding the earth surface is low and vice versa. This is due to a magnetic shielding of the earth caused by the solar activity. In addition, the solar activity has low-frequency variabilities e.g. with a time constant of several hundred years. This leads to time periods with extremely low solar activities such as e.g. during the Maunder minimum between 1645-1715. During this time period the production of cosmogenic nuclides was increased.

Finally, with the beginning of nuclear technology, humans have started to emit radioactive species into the environment. This was for the first time a serious problem during the atmospheric nuclear weapons testing programs of USA and the former Soviet Union in the late $50^{\text {th }}$ and early $60^{\text {th }}$. Most pronounced were the ejections into the atmosphere in 1962 which led to a test-stop agreement for overground explosions on 5 August 1963 in Geneva. Even now, the radioactive debris from these nuclear weapons testing period can be found in archives such as lake or sea sediments or in glacier ice cores. During the following period of underground testing only radioactive gases such as ${ }^{85} \mathrm{Kr}$ or ${ }^{37} \mathrm{Ar}$ (a secondary product from the ${ }^{40} \mathrm{Ca}(\mathrm{n}, \alpha)^{37} \mathrm{Ar}$ reaction) were released into the atmosphere.

Nuclear power plants and nuclear reprocessing plants emit radionuclides into the atmosphere too. Of special importance was the Tschernobyl accident: on April 26, 1986, due to human failure, a $1 \mathrm{GW}$ reactor exploded and caused a high contamination of the local environment. By long-range atmospheric transport Tschnerobyl fallout could be detected nearly everywhere in the northern hemisphere.

Also the non-nuclear industry releases some radionuclides into the atmosphere such as $\mathrm{T},{ }^{14} \mathrm{C}$ or several 
isotopes of iodine from tracer applications in industry, chemistry or nuclear medicine.

In the following, the main radionuclides contained in the different atmospheric compartments will be discussed, with main emphasis on their activity concentrations in the planetary boundary layer, i.e. in the lower troposphere. No general overview on all existing radionuclides will be given but rather a discussion according to decreasing average activity levels, mainly over Europe. As a lower limit, nuclides with about $\geq 1 \mathrm{mBq} / \mathrm{m}^{3}$ average activity concentration will be discussed. Therefore, some radionuclides of great importance to environmental studies but of low average activity concentration will not be included into this review. Examples of this latter category are ${ }^{10} \mathrm{Be}$ which can be used to reconstruct the history of the solar activity, ${ }^{11} \mathrm{Kr}$ as a nuclide of great potential to study very old aquatic systems, ${ }^{129} \mathrm{I}$ as a tracer to reconstruct the total emission history from nuclear industry or ${ }^{32} \mathrm{Si}$ to be used to date environmental archives over time periods between about $10^{2}$ and $10^{3}$ years.

\section{2. ${ }^{222} \mathrm{Rn}$ and its decy products}

\subsection{Radon-222}

${ }^{222} \mathrm{Rn}$ and its decay products are important atmospheric radionuclides because they are responsible for a sizable fraction of the total public exposure to ionizing radiation. Typical exhalation rates of ${ }^{222} \mathrm{Rn}$ from the soil are on the order of one atom $/ \mathrm{cm}^{2} \mathrm{~s}$ or $2 \cdot 10^{-4}$ $\mathrm{Bq} / \mathrm{cm}^{2} \mathrm{~s}$ [2]. ${ }^{222} \mathrm{Rn}$ can highly accumulate in houses, especially in cases with low ventilation rates. According to estimates [3], indoor ${ }^{222} \mathrm{Rn}$ exposure may be responsible for more than $10 \%$ of the US incidence of lung cancer. Indoor activity concentrations are typically between 10 and $10^{2} \mathrm{~Bq} / \mathrm{m}^{3}$ [3-6], for e.g. Swiss houses on the average $60 \mathrm{~Bq} / \mathrm{m}^{3}[6]$.

For outdoor conditions, emanating ${ }^{222} \mathrm{Rn}$ and its decay products distribute in the troposphere mainly via turbulent mixing which is characterized by the eddy diffusivity. Eddy diffusion is strongly depending on micrometeorological conditions. This may cause pronounced diurnal variations of the ${ }^{222} \mathrm{Rn}$ activity concentration at low altitudes (1-10 $\mathrm{m}$ above ground) [2, $5,7]$. Average diurnal variations for clear weather condition at e.g. $1.5 \mathrm{~m}$ above ground in a river valley in Germany for the time period May/July 1989 showed minimum activity concentrations of about $5 \mathrm{~Bq} / \mathrm{m}^{3}$ in the afternoon and maximum values of about $40 \mathrm{~Bq} / \mathrm{m}^{3}$ at $4 \mathrm{am}[7,8]$.

Exhalation rates of ${ }^{222} \mathrm{Rn}$ are about 100 times higher over continents if compared to the sea [9]. This leads to a gradient of the average activity concentrations of ${ }^{222} \mathrm{Rn}$ over the continent. Average values (annual means for $1980-1983$ ) were about $0.8 \mathrm{~Bq} / \mathrm{m}^{3}$ on the research platform Nordsee, $3.3 \mathrm{~Bq} / \mathrm{m}^{3}$ at Waldhof, $5 \mathrm{~Bq} / \mathrm{m}^{3}$ at Heidelberg and $6.5 \mathrm{~Bq} / \mathrm{m}^{3}$ at Krakau [10]. The surface activity concentrations of ${ }^{222} \mathrm{Rn}$ are nearly equal over the different continents, except for

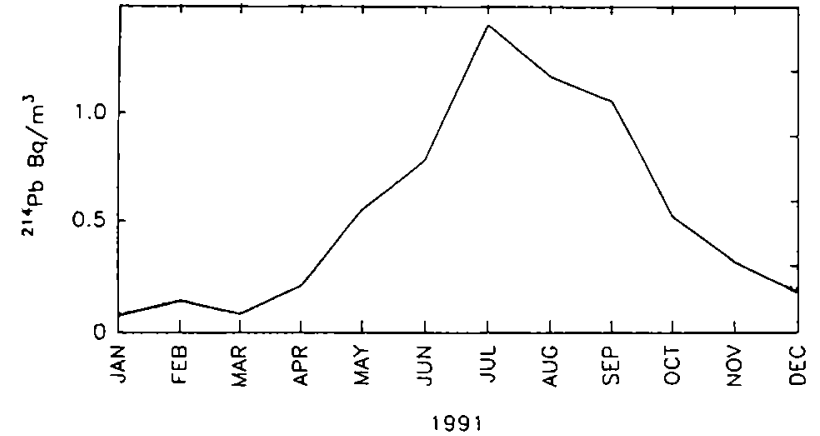

Fig. 1. Monthly mean activity concentrations of the short-lived ${ }^{222} \mathrm{Rn}$ ("radon") decay product ${ }^{214} \mathrm{~Pb}$ at Jungfraujoch $(3450 \mathrm{~m}$ asl), Switzerland, for the year 1991 (from [15]).

arctic areas [11]. For Antarctica, typical values are $(1-3) \cdot 10^{-2} \mathrm{~Bq} / \mathrm{m}^{3}[12]$. Over the sea, at distances far from land masses, ${ }^{222} \mathrm{Rn}$ activity concentrations are typically $0.1 \mathrm{~Bq} / \mathrm{m}^{3}$ [13].

This weil defined source term of ${ }^{222} \mathrm{Rn}$ makes this radionuclide a good marker for air parcels of continental or maritime origin $[11,14,15] .{ }^{222} \mathrm{Rn}$ measurements can therefore be used as an additional help to identify source regions of air masses. Examples are measurements at Jungfraujoch ( $3450 \mathrm{~m}$ asl), Switzerland. This is a high-alpine site, where high radon activities could be correlated with air trajectories arriving to this site from southerly (Africa) or easterly (continental) direction, but not from westerly direction (maritime origin) [15]. In Antarctica, high ${ }^{222} \mathrm{Rn}$ activities were connected to air mass transport from South America [12]. Another example is Mauna Loa, Hawaii, where high ${ }^{222} \mathrm{Rn}$ activity concentrations could be attributed to long-range transport from Asia [16].

The vertical concentration profile of ${ }^{222} \mathrm{Rn}$ within the planetary boundary layer is mainly determined by the atmospheric stability. The activity decreases exponentially, as predicted theoretically [17] and found experimentally $[18,19]$. Within the lowest $4 \mathrm{~km}$ it decreases by about a factor of four to ten $[19,20]$. For ground-based measurements at elevated sites, meteorological conditions strongly influence the local ${ }^{222} \mathrm{Rn}$ activity concentrations. Especially during the summer period convective vertical transport from nearby valleys cause an increase of the local activity concentrations (Fig. 1) [15, 21].

${ }^{222} \mathrm{Rn}$ activity concentrations reach values of about 10 to $100 \mathrm{mBq} / \mathrm{m}^{3}$ (STP) in the tropopause and lower stratosphere $[20,22,23]$. However, it was found that advective transport of radon-rich air from the boundary layer can reach the upper troposphere [24] or even the stratosphere [22] which can lead to bimodal distributions of the ${ }^{222} \mathrm{Rn}$ activity concentration [24].

\subsection{Short-lived decay products of ${ }^{222} \mathrm{Rn}$}

${ }^{222} \mathrm{Rn}$ decays by a chain of $\alpha$ - and $\beta$-emissions via ${ }^{218} \mathrm{Po}$ $\left(T_{1 / 2}=3.1 \mathrm{~min}\right),{ }^{214} \mathrm{~Pb}\left(T_{1 / 2}=26.8 \mathrm{~min}\right),{ }^{214} \mathrm{Bi}\left(T_{1 / 2}=\right.$ $19.9 \mathrm{~min})$ and ${ }^{214} \mathrm{Po}\left(T_{1 / 2}=164 \mu \mathrm{s}\right)$ to the long-lived 


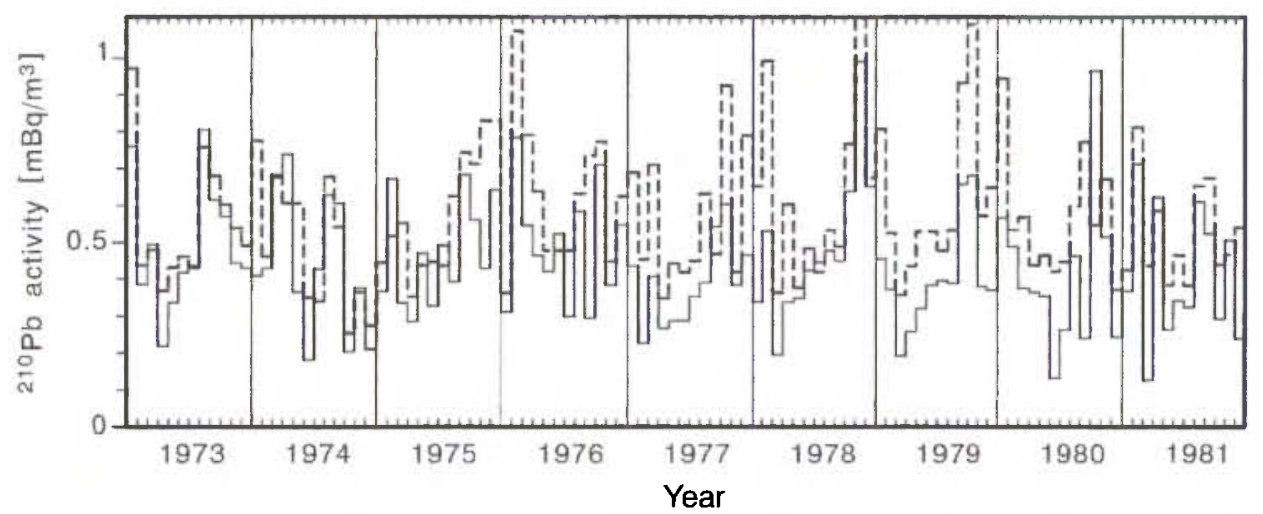

Fig. 2. Monthly mean activity concentrations of ${ }^{211} \mathrm{~Pb}$ in surface air of Fribourg, Switzerland [37] (solid line) and Neuherberg, Munich, Germany for 1973-1981 [36] (dashed line). Both sites are located on the northern side of the Alps at a distance of $360 \mathrm{~km}$.

nuclide ${ }^{210} \mathrm{~Pb}\left(T_{1 / 2}=22\right.$ years $)$. Since these progenies of radon are non-gaseous species, they adsorb to aerosol particles. It is assumed that this process proceeds in two steps. First, after thermalization of the primary nuclides in the gas, the atoms or positive ions form clusters of $0.5 \mathrm{~nm}$ to $5 \mathrm{~nm}$ size - depending on parameters such as temperature and humidity - by attachment of $\mathrm{H}_{2} \mathrm{O}$ molecules $[2,25]$. These clusters are called "unattached" radon progenies. Second, these clusters attach to aerosol particles. Typical attachment rates for outdoor conditions (aerosol particle concentration $(2-7) \cdot 10^{4} \mathrm{~cm}^{-3}$ ) were found to be $20-100 \mathrm{~h}^{-1}$ [26], corresponding to average attachment times of $40 \mathrm{~s}$ to $3 \mathrm{~min}$. For an aerosol particle concentration of only $100 \mathrm{~cm}^{-3}$, an attachment time of about 1 hour was observed [27]. Of special relevance is the fact, that due to a $112 \mathrm{keV}$ nuclear recoil, the first progeny of the $\alpha$-emitting nuclide ${ }^{218} \mathrm{Po}$, the daughter nuclide ${ }^{214} \mathrm{~Pb}$, escapes with about $80 \%$ probability [28, 29] from the particles which have typical median aerodynamic diameters of 50 to $200 \mathrm{~nm}$ [28]. In addition, for indoor condition or outdoor situations close to ground, prior to an attachment of the short-lived ${ }^{222} \mathrm{Rn}$ progenies to aerosol particles, these nuclides may plate-out to nearby-surfaces. Since the diffusion coefficients of the nm-size clusters are much higher compared to those of aerosol particles, the plate-out effect may deplete the progenies of ${ }^{222} \mathrm{Rn}$ considerably in the lowest few meters above ground [9, 17]. This is of special importance if aerosol particle collection techniques such as air-filter measurements are used to determine the ${ }^{222} \mathrm{Rn}$ activity concentrations.

At altitudes higher than about $10 \mathrm{~m}$ above ground ${ }^{222} \mathrm{Rn}$ is generally in secular equilibrium with its shortlived decay products [17].

\subsection{Lead-210}

The only long-lived ( $\geq$ years) decay product of ${ }^{222} \mathrm{Rn}$ is ${ }^{210} \mathrm{~Pb}$. This nuclides is attached to aerosol particles in the sub-micron range and therefore considered to be a good tracer for an aerosol produced by gas-toparticle conversion [30]. Its residence time in the atmosphere is determined by the average residence time of sub-micron aerosol particles from the accumulation mode which is typically one to two weeks [31, 32]. Removal from the atmosphere occurs mainly by wet and dry deposition of the carrier aerosol particles. Estimated continental deposition rates are about $20 \mathrm{mBq} / \mathrm{cm}^{2}$ y $[33,34]$. Yearly average activity concentrations in surface air over Europe are about 0.2$0.7 \mathrm{mBq} / \mathrm{m}^{3}$, except for arctic regions with lower values, e.g. $15 \mu \mathrm{Bq} / \mathrm{m}^{3}$ at Franz Joseph Island [35]. Similar to the European values are those in America, Asia and Australia [35]. Lower values are found in Antarctica, e.g. $13 \mu \mathrm{Bq} / \mathrm{m}^{3}$ at the South Pole [35].

Monthly mean activity concentrations exhibit no pronounced seasonal variation, except for some maxima during long-periods with clear weather [36-38]. Fig. 2 shows monthly mean activity concentrations for ${ }^{210} \mathrm{~Pb}$ from Fribourg, Switzerland [37] and Neuherberg, Germany [36] for the time period 1973-1981. Both locations are on the northern side of the Alps at a distance of $360 \mathrm{~km}$. The very similar concentration patterns at both locations indicates that ${ }^{210} \mathrm{~Pb}$ is well mixed in the planetary boundary layer over large areas.

Due to the long half-life of ${ }^{210} \mathrm{~Pb}$ it can be used to date environmental archives such as lake sediments or glacier ice [34]. Nuclear dating is, however, only possible if the input function is known over the time period to be determined. Surprisingly, recent ${ }^{210} \mathrm{~Pb}$ measurements in ice cores from Greenland indicated that the deposition rates changed significantly during the last 150 years $[39,40]$. Also for high-alpine ice cores recent ${ }^{210} \mathrm{~Pb}$ measurements give evidence for variations in the deposition rates over the same time period $[41,42]$. Presently there is no explanation for this observation.

The vertical profile of the ${ }^{210} \mathrm{~Pb}$ activity concentration is expected to be rather constant up to an altitude of about $10 \mathrm{~km}$ [17]. Experimental data from e.g. United States show, however, that the activity concentration of ${ }^{210} \mathrm{~Pb}$ decreases by about a factor of five within this atmospheric layer [20], presumably due to lower residence times of aerosol particles than assumed in [17]. Also data from Jungfraujoch (3450 m 
asl) yield annual mean values of about $0.2 \mathrm{mBq} / \mathrm{m}^{3}$ [15] which is a factor of two lower compared to the values at the nearby low-altitude site Fribourg [38].

\section{Decay products of ${ }^{210} \mathrm{~Pb}$}

${ }^{210} \mathrm{~Pb}$ decays via ${ }^{210} \mathrm{Bi}\left(T_{1 / 2}=5.0 \mathrm{~d}\right)$ to ${ }^{210} \mathrm{Po}\left(T_{1 / 2}=\right.$ $138.38 \mathrm{~d}$ ). Average activity concentrations of ${ }^{210} \mathrm{Po}$ in air at e.g. Neuherberg measured during 1976-1982 were found to be a factor of 10 to 20 lower than those of ${ }^{210} \mathrm{~Pb}$ [36].

Activity ratios of the decay products of ${ }^{210} \mathrm{~Pb}$ are commonly used to determine residence times of aerosol particles in the troposphere. In general, values deduced from measurements of ${ }^{210} \mathrm{Bi}$ and ${ }^{210} \mathrm{~Pb}$ are typically one week [43], in good agreement with theoretical estimates for the lower troposphere. On the other hand, residence times obtained from measurements of ${ }^{210} \mathrm{Po}$ and ${ }^{210} \mathrm{~Pb}$ are usually significantly higher, mostly about one month $[44,45]$. Such high values are discussed controversially in the literature: most authors assume additional sources of ${ }^{210} \mathrm{Po}$ besides radioactive decay of ${ }^{210} \mathrm{~Pb}[20]$ such as the soil [46, 47] or pollution sources of volcanic origin or from fossil fuel burning [47].

\section{3. ${ }^{220} \mathrm{Rn}$ and its decay products}

Due to the short half-life of about one minute, ${ }^{220} \mathrm{Rn}$ ("thoron") escapes only from a small surface soil layer into the atmosphere. For the same reason the gradient of the activity concentration in the lowest atmospheric layer is very steep, typically decreasing by more than a factor of five within the first meter above ground [9]. Since the average thorium concentration in surface soil is generally higher than that of uranium, in the atmospheric layer below $1.5 \mathrm{~m}$ above ground, ${ }^{220} \mathrm{Rn}$ activity concentrations are higher than those of ${ }^{222} \mathrm{Rn}$. Typical values measured for outdoor conditions at $1.5 \mathrm{~m}$ height in New Mexico were $22 \mathrm{~Bq} / \mathrm{m}^{3}$ for ${ }^{220} \mathrm{Rn}$ and $5.5 \mathrm{~Bq} / \mathrm{m}^{3}$ for ${ }^{222} \mathrm{Rn}$ [47]. In a flat river valley close to Göttingen strong diurnal variations of the activity concentrations of ${ }^{220} \mathrm{Rn}$ were found during a summer month, similar to those of ${ }^{222} \mathrm{Rn}$, with up to a factor of 50 higher values during night compared to the noon minima [48]. Average values at this site at the $1.5 \mathrm{~m}$ level were about $80 \mathrm{~Bq} / \mathrm{m}^{3}$ [7]. During late fall with strongly reduced vertical advective mixing, no diurnal variation of the activity concentrations for the same level above ground were observed [2].

With respect to radiation dose it is presently unclear whether the thoron decay products ${ }^{212} \mathrm{~Pb}\left(T_{1 / 2}=\right.$ $10.6 \mathrm{~h}),{ }^{212} \mathrm{Bi}\left(T_{1 / 2}=60.6 \mathrm{~min}\right)$ and ${ }^{212} \mathrm{Po}\left(T_{1 / 2}=\right.$ $0.3 \mu \mathrm{s})$ are of relevance. For indoor conditions it is estimated that these radionuclides may add up to $20 \%$ relative to that of the ${ }^{222} \mathrm{Rn}$ decay products [49].

Atmospheric measurements of ${ }^{220} \mathrm{Rn}$ decay products are scarce. In Malaga, Spain, close to the sea shore, during a 6 month measuring campaign of air collected $2 \mathrm{~m}$ above ground, ${ }^{212} \mathrm{~Pb}$ activity concentrations of about $0.1 \mathrm{~Bq} / \mathrm{m}^{3}$ and ${ }^{222} \mathrm{Rn}$ activity concentrations of about $2 \mathrm{~Bq} / \mathrm{m}^{3}$ were determined [50]. Continuous measurements of ${ }^{212} \mathrm{~Pb}$ over 3.5 months in a river valley close to Göttingen resulted in average activity concentration of $0.4 \mathrm{~Bq} / \mathrm{m}^{3}$, with large variations of the single measurements by nearly two orders of magnitude [48]. At Mauna Loa, ${ }^{212} \mathrm{~Pb}$ activity concentrations were strongly depending on meteorological conditions with up to $4 \mathrm{mBq} / \mathrm{m}^{3}$ for up-slope wind conditions and much lower values for non-up-slope wind conditions [51]. At Jungfraujoch, ${ }^{212} \mathrm{~Pb}$ monthly mean activity concentrations showed large variations with minimum values of $1 \mathrm{mBq} / \mathrm{m}^{3}$ in winter and maximum values of $8 \mathrm{mBq} / \mathrm{m}^{3}$ in summer [15].

\section{Krypton-85}

${ }^{85} \mathrm{Kr}$ is a noble gas isotope with a half-life of 10.76 years. It is produced in the thermal neutron induced fission of ${ }^{235} \mathrm{U}$ with a cumulative yield of $0.28 \%$, which is the product of the isobaric chain yield of $1.32 \%$ and the yield of the internal transition of ${ }^{85 m} \mathrm{Kr}$ of $21.4 \%$. This radionuclide is emitted into the atmosphere during nuclear weapons testing (both above and underground), from nuclear power plants as well as from nuclear reprocessing plants. The average activity concentrations of ${ }^{85} \mathrm{Kr}$ in the northern hemisphere is presently slightly higher than $1 \mathrm{~Bq} / \mathrm{m}^{3}$ [52]. Its activity concentration is steadily increasing with a doubling time of about 20 years [53]. At collection sites within the planetary boundary layer, activity peaks are frequently observed, presumably due to well defined releases from reprocessing plants $[53,54]$. At Jungfraujoch, which is in the free troposphere, the average activity concentration of ${ }^{85} \mathrm{Kr}$ is also about $1 \mathrm{~Bq} / \mathrm{m}^{3}$ but with much less pronounced fluctuations with time [52]. This means that this radionuclide is well mixed in the troposphere of the northern hemisphere [54]. In antarctica, the activity concentration of ${ }^{85} \mathrm{Kr}$ is about $20 \%$ lower compared to the values in the northern hemisphere [53]. This is caused by the average transportation time from the emission sources, all being in the northern hemisphere, to Antarctica, which is on the order of a few years.

Even though ${ }^{85} \mathrm{Kr}$ is the artificial radionuclide with the highest average activity concentration in the troposphere, its radiological importance is negligible, because - unlike ${ }^{222} \mathrm{Rn}$ - it has no non-gaseous radioactive decay products which can be accumulated in the human body.

\section{Tritium}

Tritium $\left({ }^{3} \mathrm{H}=\mathrm{T}\right)$ is a weak $\beta$-emitter $\left(E_{\beta}=18 \mathrm{keV}\right)$ with a half-life of 12.3 years. Tritium is both of natural and anthropogenic origin. The natural production occurs via interaction of cosmic rays with the atmosphere. The anthropogenic production has several 


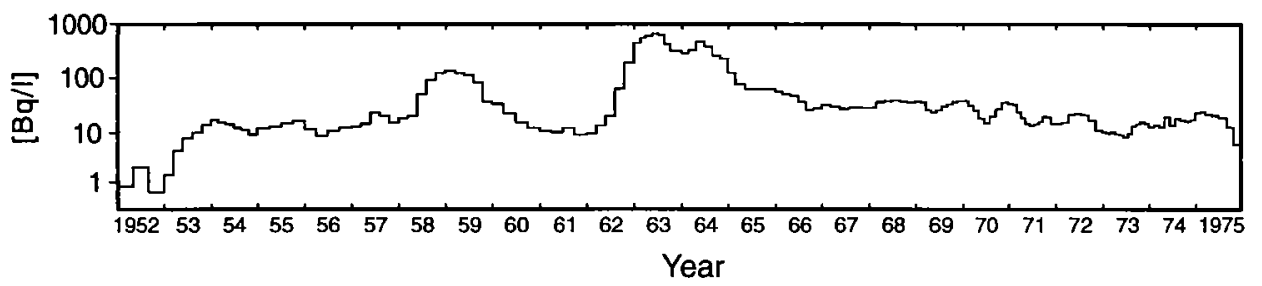

Fig. 3. Tritium activity concentration (corrected for decay) from an ice core from Colle Gnifetti ( $4450 \mathrm{~m}$ asl), Monte Rosa massif (from [37]). The dating is based on the observation of well documented stratigraphic layers (Saharan dust horizons etc.).

sources. First, tritium was released to the atmosphere by thermonuclear explosions. Second, a release into the atmosphere occurs from nuclear power plants or reprocessing plants as well as from industry. Due to its widespread applications, the actual tropospheric activity concentration of tritium is significantly increased compared to the natural level from prenuclear times. The activity concentration of tritium is often given in T.U. (Tritium Units), with $1 \mathrm{TU}=1 \mathrm{~T}$ atom per $10^{18} \mathrm{H}$ atoms. 1 T.U. corresponds to a specific tritium activity of $0.12 \mathrm{~Bq} / \mathrm{kg}$ water.

In the atmosphere - except for the upper stratosphere - the dominating species containing tritium is HTO $[55,56]$. Most of the tritium is deposited on the earth surface by precipitation. However, depending on humidity and temperature, in the atmosphere a large part of tritium is in form HTO vapor. Due to isotopic enrichment, the $\mathrm{T} / \mathrm{H}$ ratio in liquid $\mathrm{HTO}$ is 1.1 higher compared to that in gaseous HTO [57]. Some minor part of tritium is also found in form of HT.

\subsection{Natural tritium}

As a cosmogenic radionuclide, tritium is produced in the stratosphere in spallation reactions of galactic cosmic rays, mainly protons, with oxygen and nitrogen. In addition, tritium is also produced by secondary particles, high-energy ( $E \geq 4.4 \mathrm{MeV}$ ) neutrons in the ${ }^{14} \mathrm{~N}(\mathrm{n}, \mathrm{T}){ }^{12} \mathrm{C}$ reaction. As for all cosmogenic radionuclides, the rate of production depends on the solar activity and varies between $(1.5-3) \cdot 10^{17} \mathrm{~Bq} /$ year [56]. Maximum solar flares correspond to minimum production and vice versa.

The specific natural tritium concentration in precipitation depends on the latitude, with about $5 \mathrm{~Bq} / 1$ at the poles and $0.06 \mathrm{~Bq} / 1$ at the equator [57]. For a latitude of $45^{\circ} \mathrm{N}$ or $\mathrm{S}$, the natural specific tritium activity concentration is about $0.6 \mathrm{~Bq} / \mathrm{l}$. This behavior is caused by the stratosphere-troposphere exchange of air masses [57, 58]. In addition, increased downward air mass flow is observed in late spring [55, 59]. This leads to seasonal fluctuations of the tropospheric activity concentration with maxima in late spring [57].

There exists a continental effect of the specific tritium activity concentration with lower values for sites close to the sea shore compared to those located deep inside the continents [57]. For sites close to the coast the isotopic composition of HTO corresponds to that of oceanic surface water whereas for inland sites the
HTO composition is increasingly determined by the tropospheric values at this latitude and by evaporated water from the land surface.

For tritium in form of HT, the specific activity is much higher. However, due to the low abundance of hydrogen in air, the total amount of natural tritium in form of HT is only about $10^{-4}$ compared to that in form of HTO [55].

\subsection{Anthropogenic tritium}

Begemann and Libby [60] estimated, that about $4 \cdot 10^{17} \mathrm{~Bq}$ of tritium was released for each megaton thermonuclear explosion. The total amount of tritium released during the overground test series performed by USA and USSR between 1954 and 1963 is estimated to be about $1.1 \cdot 10^{20} \mathrm{~Bq}$ [55].

French and Chinese tests between 1968 and 1977 have added another $(7-10) \cdot 10^{18} \mathrm{~Bq}[55]$. These nuclear tests have, of course, strongly increased the HTO concentration in the atmosphere. As an example, the measured tritium concentrations in precipitation, as determined from an Alpine glacier ice core from Colle Gnifetti (4450 m asl) near Zermatt, Switzerland, for the time period $1952-1975$ is shown in Fig. 3 [37, 61]. From a level of about $1 \mathrm{~Bq} / 1$ in 1952 the tritium activity concentration increased to $740 \mathrm{~Bq} / 1$ in 1963 and then decreased to about $10 \mathrm{~Bq} / 1$ in 1975 . Since the snow deposition at this high-alpine wind exposed site occurs not very regularly [62], the seasonal fluctuation of the tritium deposition is not well preserved. Between 1975 and present, the tritium activity concentration decreased further. Typical tritium activity concentrations in precipitation, e.g. 1993 in Switzerland at different locations were between 1.5 and $5.5 \mathrm{~Bq} / 1$ $[6,63]$. The reasons for a still increased level of tritium compared to the natural background level are industrial applications, such as e.g. from the production of luminous dials.

\subsection{Atmospheric activity concentration of tritium}

If we assume, as an example for 1992, an average relative humidity of $70 \%$ and an average winter and summer temperature of $2{ }^{\circ} \mathrm{C}$ and $20^{\circ} \mathrm{C}$, respectively (values for Zürich, Switzerland [64, 65]), the measured tritium activity concentrations in precipitation of about 


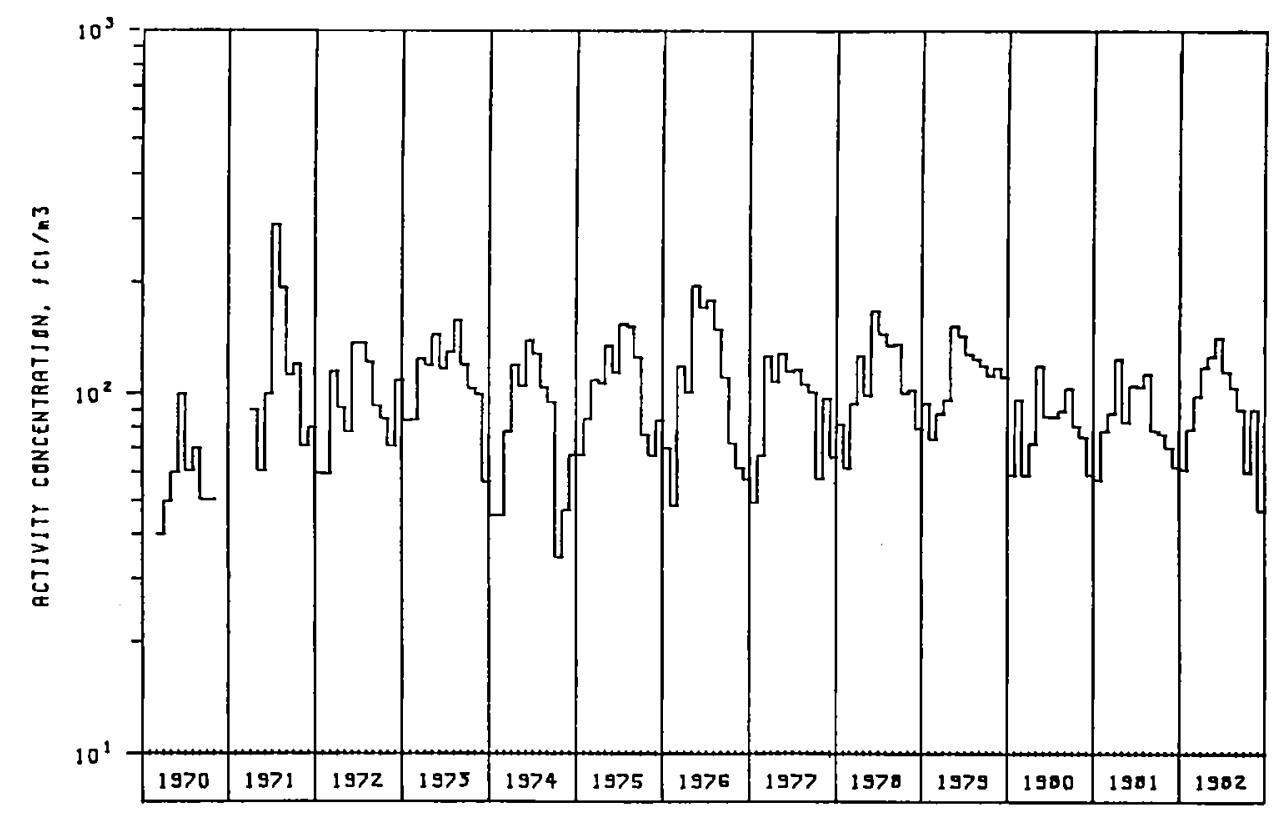

Fig. 4. Monthly mean activity concentrations of ${ }^{7} \mathrm{Be}$ in surface air of Neuherberg, Germany (from [36]). Activities are given in femtocurie $/ \mathrm{m}^{3} .100 \mathrm{fCi} / \mathrm{m}^{3}=3.7 \mathrm{mBq} / \mathrm{m}^{3}$.

$2 \mathrm{~Bq} / 1$ corresponds to an average activity concentrations of gaseous HTO of 8 to $24 \mathrm{mBq} / \mathrm{m}^{3}$ for winter and summer, respectively. However, for the same year, in the neighborhood of a company using tritium for industrial applications, much higher gaseous HTO activity concentrations of about $5-25 \mathrm{~Bq} / \mathrm{m}^{3}$ have been measured [52].

\section{Beryllium-7}

${ }^{7} \mathrm{Be}$ is a cosmogenic radionuclide with a half-life of $53.3 \mathrm{~d}$. It is produced both by primary (mostly protons) and secondary (neutrons) cosmic ray particles with nitrogen and oxygen according to the following reactions: ${ }^{14} \mathrm{~N}(\mathrm{p}, 2 \alpha){ }^{7} \mathrm{Be},{ }^{16} \mathrm{O}\left(\mathrm{p},{ }^{10} \mathrm{~B}\right){ }^{7} \mathrm{Be},{ }^{14} \mathrm{~N}\left(\mathrm{n},{ }^{8} \mathrm{Li}\right){ }^{7} \mathrm{Be}$, and ${ }^{16} \mathrm{O}\left(\mathrm{n},{ }^{10} \mathrm{Be}\right){ }^{7} \mathrm{Be}$.

About $67 \%$ of ${ }^{7} \mathrm{Be}$ is produced in the stratosphere and $33 \%$ in the troposphere [66]. The peak production is approximately in the middle of the atmosphere (in mass units) [67]. After production, ${ }^{7} \mathrm{Be}$ attaches to submicron-sized aerosol particles [68]. Cascade impactor measurements showed that in ambient aerosol particles most of the ${ }^{7} \mathrm{Be}$ was found in the 0.7 to $1.1 \mu \mathrm{m}$ range [69]. Due to its main $\gamma$-line at $478 \mathrm{keV}$ this nuclide can be easily measured in air filter samples. The surface activity concentration of ${ }^{7} \mathrm{Be}$ in air depends on four processes [70], i) stratosphere-troposphere exchange, ii) downward transport in the troposphere, iii) wet scavenging, and iv) horizontal transfer from mid latitudes to higher and lower latitudes. Hence, the annual cycle of ${ }^{7} \mathrm{Be}$ in surface air may be quite different at different sites. For mid latitudes in the northern hemisphere, typical annual cycles with maximum activity concentrations in early summer are found (Fig. 4), caused by tropopause folding during this time period. In polar regions or at subtropical locations the annual cycles of ${ }^{7} \mathrm{Be}$ activity concentrations are more complex as shown in a very thorough review on ${ }^{7} \mathrm{Be}$ in the atmosphere [71].

The question whether the surface activity concentration of ${ }^{\urcorner} \mathrm{Be}$ depends on the solar activity is discussed controversially. In Ref. [71] no such clear correlation was found in contrast to Ref. [72], where for the years $1985-1990$ at 8 stations from $71^{\circ} \mathrm{N}$ to $53^{\circ} \mathrm{S}$ a pronounced decrease of the annual mean activity concentration was correlated to an increase of the solar activity (sun spot number) for the same time period [73].

The annual mean surface activity concentrations are higher at low latitudes compared to high latitudes, which is somewhat different to expectations based on pure vertical stratosphere-troposphere exchange. This might be a result of the complex transport processes mentioned above. As an example, the annual mean activity concentrations for 1987 were (in $\mathrm{mBq} / \mathrm{m}^{3}$ ): 1.4 in Barrow, Alaska $\left(71^{\circ} \mathrm{N}\right), 2.9$ in Moosonee, Canada $\left(51^{\circ} \mathrm{N}\right), 4.5$ in Chester, USA $\left(41^{\circ} \mathrm{N}\right), 5.4$ in Miami, USA $\left(26^{\circ} \mathrm{N}\right), 4.5$ in Lima, Peru $\left(12^{\circ} \mathrm{S}\right), 4.8$ in Perth, Australia $\left(32^{\circ} \mathrm{S}\right), 3.5$ in Cape Grim, Tasmania, Australia $\left(41^{\circ} \mathrm{S}\right)$, and 1.7 in Punta Arenas, Chile $\left(53^{\circ} \mathrm{S}\right)$, respectively [72]. In Europe (e.g. Neuherberg, Germany, or Fribourg, Switzerland), annual man values in surface air are about $3 \mathrm{mBq} / \mathrm{m}^{3}[36,37]$.

The activity concentrations are increasing with altitude. For northern mid latitudes typical values are $18 \mathrm{mBq} / \mathrm{m}^{3}$ at the tropopause and $155 \mathrm{mBq} / \mathrm{m}^{3}$ in the lower stratosphere [74].

\section{Carbon-14}

${ }^{14} \mathrm{C}\left(T_{1 / 2}=5730\right.$ years $)$ is a pure $\beta$-emitter with a maximum energy of $0.2 \mathrm{MeV}$. Similar to tritium, also modern atmospheric ${ }^{14} \mathrm{C}$ is of natural and anthropogen- 
ic origin. Natural ${ }^{14} \mathrm{C}$ is mainly produced in interactions of secondary cosmic ray particles (neutrons) with nitrogen, according to the reaction ${ }^{14} \mathrm{~N}(\mathrm{n}, \mathrm{p}){ }^{14} \mathrm{C}$. About $55 \%$ of ${ }^{14} \mathrm{C}$ is produced in the stratosphere and $45 \%$ in the upper troposphere [75]. Primary ${ }^{14} \mathrm{C}$ oxidizes immediately in the atmosphere to ${ }^{14} \mathrm{CO}_{2}$. The average natural atmospheric activity concentration of ${ }^{14} \mathrm{C}$ is about $40 \mathrm{mBq} / \mathrm{m}^{3}$ air, based on a measured specific activity of $0.219 \mathrm{~Bq}{ }^{14} \mathrm{C} / \mathrm{g}$ total carbon [76] and an atmospheric volume concentration of $0.033 \% \mathrm{CO}_{2}$. This corresponds to a ${ }^{14} \mathrm{C} /{ }^{12} \mathrm{C}$ ratio of $1.2 \cdot 10^{-12}$. The largest reservoir of ${ }^{14} \mathrm{C}$ is the ocean $(94 \%)$, the residual part being distributed in the atmosphere $(1.5 \%)$, biosphere $(2.0 \%)$ and the humus $(2.5 \%)$ [77].

${ }^{14} \mathrm{C}$ is incorporated into living material via $\mathrm{CO}_{2}$ uptake. This nuclide has therefore found widespread applications for dating purposes of dead organic material with an age up to 32,000 years [77]. By comparing "true" ages from dendrochronology of tree rings with the ${ }^{14} \mathrm{C}$-age of the carbon from the corresponding annual layers it was found that the past atmospheric ${ }^{14} \mathrm{C}$ activity concentration was not constant. The longest period of the observed activity fluctuations has a period of about 11,000 years and is attributed to geomagnetic dipole fluctuations of the earth [78]. The shortest fluctuation is caused by the well known 11-year cycle of the solar activity. The amplitudes of these activity fluctuations are usually $\leq 2 \%[79]$.

With the beginning of the nuclear age, anthropogenic ${ }^{14} \mathrm{C}$ was introduced into the atmosphere. In the years 1962/63 with maximum overground testing of thermonuclear weapons, the ${ }^{14} \mathrm{C}$ activity concentration in the northern hemisphere increased by nearly a factor of two [80]. In the southern hemisphere the increase was much smaller [81]. After the stop of overground nuclear explosions in 1963 the anthropogenic ${ }^{14} \mathrm{G}$ activity concentration decreased significantly, every 17 years be a factor of two [81]. Actual ${ }^{14} \mathrm{C}$ activity concentrations are still increased by about $10 \%$ above the natural level, mainly as residual contribution from the nuclear explosions but also due to emissions from nuclear power plants, reprocessing plants and from ${ }^{14} \mathrm{C}$ tracer applications in chemistry. This means that the actual ${ }^{14} \mathrm{C}$ activity concentration in the troposphere is about $45 \mathrm{mBq} / \mathrm{m}^{3}$.

Besides the anthropogenic increase of the ${ }^{14} \mathrm{C}$ activity concentration there exists also an anthropogenic decrease which is caused by human fossil fuel burning. In 1950 it was realized by Suess that ${ }^{14} \mathrm{C}$ activities in modern wood samples were too low by about $2 \%$ [82]. This so-called Suess effect was later masked by the much larger increase of the ${ }^{14} \mathrm{C}$ activity concentration from the nuclear weapons testing.

\section{Argon-37}

${ }^{37} \mathrm{Ar}$ decays via electron capture and has a half-life of $35 \mathrm{~d}$. It is produced in cosmic ray induced reactions with atmospheric argon. In underground nuclear

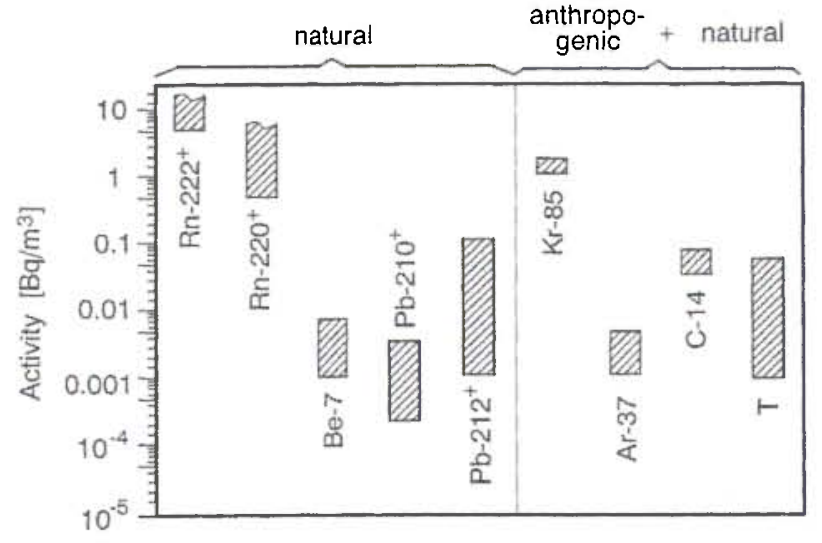

Fig. 5. Average activity concentrations of those radionuclides which have values above about $1 \mathrm{mBg} / \mathrm{m}^{3}$ in surface air over continents - mainly over Europe. The sign ${ }^{+}$means that also short-lived decay products of these nuclides have similar activity concentrations.

weapons tests it is formed in the ${ }^{40} \mathrm{Ca}(\mathrm{n}, \alpha)^{37} \mathrm{Ar}$ reaction. Some release of this nuclide occurs also from nuclear facilities [6]. In surface air the natural activity concentration from cosmic ray production is about $0.5 \mathrm{mBq} / \mathrm{m}^{3}$ [6]. During the early $70^{\text {th }}$ with large underground test series, the ${ }^{37} \mathrm{Ar}$ activity concentration e.g. in Bern, Switzerland, was increased shortly after every explosion by about a factor of 100 [37]. Presently, the activity concentration at the same location is between 0.6 and $3.8 \mathrm{mBq} / \mathrm{m}^{3}$ [6].

\section{Summary}

Typical ranges of actual surface air activity concentrations of different radionuclides over continents are shown in Fig. 5. Only those nuclides are depicted which presently have average activity concentrations above about $1 \mathrm{mBq} / \mathrm{m}^{3}$. Highest values have ${ }^{222} \mathrm{Rn}$ ("radon") and ${ }^{220} \mathrm{Rn}$ ("thoron") including their shortlived decay products. Over the sea, the highest activity concentration has the anthropogenic radionuclide ${ }^{85} \mathrm{Kr}$, due to the much reduced emanation rates of radon and thoron from the oceans.

Fig. 5 also shows that the highest tropospheric activity concentration from all cosmogenic radionuclides has ${ }^{14} \mathrm{C}$, even though about $10 \%$ of its present-day activity is caused by anthropogenic sources.

The gaseous radionuclides shown in Fig. 5 are ${ }^{222} \mathrm{Rn},{ }^{220} \mathrm{Rn},{ }^{85} \mathrm{Kr},{ }^{37} \mathrm{Ar},{ }^{14} \mathrm{C}$ (in form of $\mathrm{CO}_{2}$ ), and $\mathrm{T}$ (in form of water vapor). They are of minor importance with respect to public exposure to ionizing radiation. This is different for those radionuclides which are attached to aerosol particles such as the decay products of ${ }^{222} \mathrm{Rn}$ and ${ }^{220} \mathrm{Rn}$ but also for ${ }^{7} \mathrm{Be}$ because they can be accumulated in the human respiratory organ.

Not included in this review are those radionuclides which were released during the Tschernobyl accident on April 26, 1986 because they caused a contaminations of tropospheric air masses over a few days 
only, e.g. in Switzerland between about April 30 and Mai 3, 1986 [83].

\section{References}

1. Reedy, R. C.: Science 219127 (1983).

2. Porstendörfer, J.: J. Aerosol Sci. 25, 219 (1994), and references therein.

3. Bruno, R. C.: J. Air Pollut. Control. Ass. 33, 105 (1983).

4. Burkart, W.: Nucl. Technol. 60, 114 (1983).

5. Jacobi, W.: Health Phys. 22, 441 (1972).

6. Environmental Radioactivity and Radiation Exposure in Switzerland 1993, Bundesamt für Gesundheitswesen, Bern, ISBN 3-905235-15 (1994).

7. Butterweck, G., Reineking, A., Kesten, J., Porstendörfer, J.: Atmos. Environ. 28, 1963 (1994).

8. Porstendörfer, J., Butterweck, G., Reineking, A.: Health Phys., in press.

9. Jacobi, W.: Die natürliche Radioaktivität der Atmosphäre und ihre Bedeutung für die Strahlenbelastung des Menschen, Hahn Meitner Institut, Berlin, Report HMJ-B21 (1962), in german.

10. Volpp, H. J.: Untersuchung des großräumigen atmosphärischen Transports in Mitteleuropa mit Hilfe von ${ }^{222} \mathrm{Rn}$. Doctoral thesis, Universität Heidelberg (1984), unpublished.

11. Feichter, J., Crutzen, P. J.: Tellus 42B, 46 (1990).

12. Pereira, E. B.: Tellus 42B, 39 (1990).

13. Lambert, G., Ardouin, B., Sanak, J.: Tellus 42B, 76 (1990).

14. Heimann, M., Monfray, P., Polian, G.: Tellus 42B, 83 (1990).

15. Gäggeler, H. W., Jost, D. T., Baltensperger, U., Schwikowski, M., Seibert, P. : Atmos. Environ. 29, 607 (1995).

16. Whittlestone, S., Robinson, E., Ryan, S.: Atmos. Environ. 26A, 251 (1992).

17. Jacobi, W., André, K.: J. Geophys. Res. 68, 3799 (1963).

18. Nazarov, L. E., Kuzenkov, F., Malakhov, S. G., Volokitina, L. A., Gaziyev, Ya. I., Vasil'yev, A. S.: J. Geophys. Res. 75, 3575 (1970).

19. Lambert, G., Polian, G., Sanak, J., Ardouin, B., Buisson, A., Jegou, A., Le Roulley, J. C.: Ann. Géophys. 38, 497 (1982).

20. Moore, H. E., Poet, S. E., Martell, E. A.: J. Geophys. Res. 78, 7065 (1973).

21. Reiter, R., Munzert, K.: Arch. Met. Geoph. Biokl., Ser. B, 31, 39 (1982).

22. Lambert, G., Le Roulley, J.-C., Kritz, M.: Tellus 42B, 135 (1990).

23. Liu, S. C., McAfee, J. R., Cicerone, R. J.: J. Geophys. Res. 89, 7291 (1984).

24. Kritz, M. A., LeRoulley, J. C., Danielsen, E. F.: Tellus 42B, 46 (1990).

25. Rogak, S. N., Baltensperger, U., Flagan, R. C.: Aerosol Sci. and Techn. 14, 447 (1991).

26. Porstendörfer, J., Mercer, T. T.: Atmos. Environ. 12, 2223 (1978).

27. Whittlestone, S.: J. Atmos. Chem. 11, 27 (1990).

28. Mercer, T. T.: Health Phys. 31, 173 (1976).

29. Mercer, T. T., Stowe, W. A.: Radioactive Aerosols produced by radon in room air, in: Inhaled Particles III (Edited by W. H. Walton, Unwin, Old Woking (1971).

30. Sanak, J., Gaudry, A., Lambert, G.: Geophys. Res. Lett. 8, 1067 (1981).

31. Poet, S. E., Moore, H. E., Martell, E. A.: J. Geophys. Res. 77, 6515 (1972).

32. Francis, C. W., Chesters, G., Haskin, L. A.: Environ. Sci. Technol. 4, 587 (1970).

33. El-Dahoushy, F.: Proc. First Int. Summer School on LowLevel Measurements and Their Applications to Environmental Radioactivity, La Rabida, Andalusia, Spain 1987, Published by World Scientific, M. Garcia-Leon and G. Madurga (Eds.), p. 224-273 (1988).

34. von Gunten, H. R., Moser, R. N.: J. Paleolimnol. 9, 161 (1993).
35. Rangarajan, C., Madhavan, R., Gopalakrishnan, S. S.: J. Environ. Radioact. 3, 23 (1986).

36. Report Gesellschaft für Strahlen- und Umweltforschung mbH München, GSF, S-956, ISSN-0721-1694 (1983), in german.

37. Report "25 Jahre Radioaktivitätsüberwachung in der Schweiz", KUER, c/o Physics Institute, University of Fribourg, Switzerland (1982), unpublished.

38. Gäggeler, H., von Gunten, H. R., Nyffeler, U.: Earth Plan. Sci. Lett. 33, 119 (1976).

39. Nijampurkar, V. N., Clausen, H. B.: Tellus 42B, 29 (1990).

40. Dibb, J. E.: Tellus 44B, 72 (1992).

41. Gäggeler, H., von Gunten, H. R., Rössler, E., Oeschger, H., Schotterer, U.: J. Glaciol. 29, 165 (1983).

42. Gäggeler, H. W., von Gunten, H. R., Füeg, B.: unpublished data (1995).

43. Rangarajan, C., Eapen, C. D.: Tellus 42B, 142 (1990) and references therein.

44. Anand, S. J. S., Rangarajan, C.: J. Environ. Radioact. 11, 235 (1990).

45. Kuroda, P. K., Daniel, P. Y., Nevissi, A., Beck, J. N., Meason, J. L.: J. Radioanal. Chem. 43, 443 (1978).

46. Moore, H. E., Martell, E. A., Poet, S. E.: Environ. Sci. Technol. 10, 586 (1976).

47. Zarcone, M. J., Schery, S. D., Wilkening, M. H., McNamee, E.: Atmos. Environ. 20, 1273 (1986).

48. Porstendörfer, J., Butterweck, G.: unpublished data referred to in Ref. [2] (1991).

49. Schery, S. D.: J. Air Waste Manage. Assoc. 40, 493 (1990).

50. Duenas, C., Fernandez, M. C., Senciales, M.: Atmos. Environ. 24A, 1255 (1990).

51. Whittlestone, S., Schery, S. D., Yanxia, Li: Climate Monitoring and Diagnostocs Laboratory, National Oceanic and Atmospheric Administration, U.S. Depart of Commerce, CMDL Summary Report 1992, Boulder, Colorado (1993).

52. Umweltradioaktivität und Strahlendosen in der Schweiz 1992, Bundesamt für Gesundheitswesen, Abteilung Strahlenschutz, Chemin du Musée 3, CH-1700 Fribourg, ISBN 3-905235-09-9 (1993), in german.

53. Weiss, W., presented at: Seminar uiber Umweltbelastung durch langlebige künstlich erzeugte Radionuklide, Verkehrshaus, Luzern, Switzerland, 29. Juni 1995, KUER/KSA Organizers, unpublished.

54. Wilhelmova, L., Tomasek, M., Stukheil, K. : J. Radioanal. Nucl. Chem. Lett. 144, 125 (1990).

55. see e.g. in: A. C. Chamberlin, Radioactive aerosols, Cambridge Environmental Chemistry Series, Cambridge University Press, ISBN 0-521-40121-6 (1991).

56. Tritium in the environment. National Council on Radiation Protection and Measurements (NCRP), Washington DC (1979).

57. Hebert, D.: Tritium in der Atmosphäre - Quellen, Verteilung, Perspektive -, Freiberger Forschungshefte, C 443 Geowissenschaften, ISSN 0071-9404, VEB Deutscher Verlag für Grundstoffindustrie, Leipzig (1990), in german.

58. Douglass, A. R., Stanford, J. L. : J. Geophys. Res. 87, 5001 (1982).

59. Ehalt, D. H.: J. Geophys. Res. 76, 7351 (1971).

60. Begemann, F., Libby, W. F.: Geochim. Cosmochim. Acta 12, 277 (1957).

61. Oeschger, H., Schotterer, U., Stauffer, B., Haeberli, W., Röthlisberger, H., Gäggeler, H. W.: Z. Gletscherk. Glazialgeol. 13, 193 (1977).

62. Schotterer, U., Oeschger, H., Wagenbach, D., Münnich, K. O.: Z. Gletscherk. Glazialgeol. 21, 379 (1985).

63. Schotterer, U.: priv. comm. (1995)

64. Lugauer, M.: priv. comm. (1995).

65. Schriftreihe Umwelt Nr. 207 Luft. NABEL Luftbelastung 1992, Bundesamt für Umwelt, Wald und Landschaft (Eds.), Bern, August (1993), in german.

66. Lal, D., in: Earth Science and Meteoritics, compiled by J. Geiss and E. D. Goldberg 312 pp., North Holland, New York (1963). 
67. Junge, C. E.: Air Chemistry and Radioactivity, 382 pp., Academic, San Diego, Calif. (1963).

68. Bondietti, E. A., Hoffman, F. O., Larsen, I. L.: J. Environ. Radioact. 1, 5 (1984).

69. Papastefanou, C., Ioannidou, A.: J. Environ. Radioact. 26, 273 (1995).

70. Feely, H. W., Larsen, R. J., Sanderson, C. G.: Annual Report of the surface air sampling program, July 1988, Rep. EML497, Environ. Meas. Lab., U.S. Dept. of Energ., New York (1988).

71. Brost, R. A., Feichter, J., Heimann, M.: J. Geophys. Res. D12, $22^{\prime} 423$ (1991).

72. Larsen, R. J.: J. Environ. Radioact. 18, 85 (1993).

73. Barry, R. G., Chorley, R. J.: The sun spot number between 1610 and 1990, Atmosphere, Weather and Climate, $6^{\text {th }}$ ed., Rontledge, London (1992).

74. Dutkiewicz, V. A., Husain, L.: Geophys. Res. Lett. 6, 171 (1979).

75. Damon, P. E., Sternberg, R. E.: Radiocarbon 31(3), 697 (1989).

76. Hagemann, F. T., Gray Jr., J., Machta, L., Turkevich, A.: Science 130, 542 (1959).
77. Stuiver, M.: Nature 273, 271 (1978).

78. see e.g.: Méthodes de datation par les phénomènes nucléaires naturels application, E. Roth, B. Poty (Eds.), Masson, Paris, New York, Barcelone, Milan, Mexico, Sao Paulo (1985).

79. Hauenstein, J.: Herstellung von mikrogramm-großen Kohlenstoffproben für die Bestimmung des ${ }^{14} \mathrm{C}$ Gehaltes sowie Untersuchung von fossilen Pollen und polarem Gletschereis, Dissertation, Universität Bern, Switzerland (1994), unpublished (in german).

80. Levin, I., Bösinger, R., Bonani, G., Francey, R. J., Kromer, B., Münnich, K. O., Suter, M., Trivet, N. E. A., Wölfli, W., in: Radiocarbon after four decades, eds. R. E. Taylor, A. Long, R. S. Kra, Springer Verlag, pp 503-518 (1992).

81. Kaimei, D., Youneng, Q., Fan, C. Y.: Radiocarbon 34(3), 753 (1992).

82. Suess, H. E.: Natural radiocarbon and the rate of exchange of carbon dioxide between the atmosphere and the sea, Proc. Williams Bay Conf. Sept. 1953, NAS-NSF Publ. 52 (1954).

83. Jost, D. T., Gäggeler, H. W., Baltensperger, U., Zinder, B., Haller, P.: Nature 324, 22 (1986). 
